\title{
A CONSTITUIÇÃO DE WEIMAR E O CONSTITUCIONALISMO DO AUTORITARISMO PORTUGUÊS
}

\section{THE WEIMAR CONSTITUTION AND PORTUGUESE AUTHORITARIAN CONSTITUTIONALISM}

\author{
Paula Borges Santos \\ Instituto de História Contemporânea, Faculdade de Ciências Socais e Humanas \\ da Universidade Nova de Lisboa
}

\begin{abstract}
SUMÁRIO: I. INTRODUÇÃO - II. WEIMAR RECEPCIONADA PELA REPÚBLICA PORTUGUESA (1919-1926) - 2.1. O estudo da Constituição alemã de 1919 na disciplina de Economia Social - III. A ECONOMIA SOCIAL E AS TRADIÇÕES E MODERNIZAÇÕES DO DIREITO E DO TRABALHO NA EUROPA - IV. O PROCESSO DE CONSTITUCIONALIZAÇÃO E A AMBIÇÃO DE REFORMA DO ESTADO - 4.1 A adaptação do constitucionalismo de Weimar na Constituição de 1933 - V. CONCLUSÃO: A CONSTITUIÇÃO DE 1933 E O MOVIMENTO CONSTITUCIONAL NO SÉCULO XX PORTUGUÊS
\end{abstract}

Resumo: É possivel a Constituição de Weimar de 1919, orientada por fórmulas democráticas, ter servido de inspiração a constitucionalismos de matriz autoritária? A resposta, tão paradoxal quanto a pergunta, é afirmativa. O caso da Constituição Política do Estado autoritário em Portugal, elaborada entre 1930 e 1933, confirma essa hipótese. São vários os seus preceitos que têm como fonte as inovações que tinham dado ao texto constitucional de Weimar o carácter pioneiro que teve na Europa do começo do século XX, designadamente os que estabelecem referências à família, às corporações morais e económicas, o desenvolvimento de matérias económicas e a eleição do presidente da República por sufrágio directo.

Neste artigo analisa-se como se deu a receção daquela Constituição alemã em Portugal e exploram-se os fundamentos para o acolhimento de conteúdos constitucionais, associados a um governo democrático moderno, por um poder constituinte empenhado um criar uma nova ordem estatal não democrática. Observam-se, para esse efeito, três questões: a primeira, que envolve saber como foi percebida, por políticos e juristas, a República de Weimar e em particular a sua Constituição, na década de 1920, em Portugal; a segunda, que discute quais os problemas políticos e sociais a que pretendeu responder o legislador constituinte de 1933, considerando que aí reside a chave para entender aspetos de importação e de adaptação do fenómeno constitucional weimeriano pelas elites políticas e jurídicas do Estado Novo. Por fim, a terceira questão que indaga sobre o sentido do que aqui chamo "movimento constitucional" do século XX português, discutindo se a Constituição de 1933 introduziu ou não características da organização política, em particular, e do Estado, em geral, que se impuseram no decurso dessa temporalidade e que ainda marcam o atual regime democrático. 
Abstract: Might the 1919 Weimar Constitution, structured according to democratic formulas, have served as the inspiration for an authoritarian form of constitutionalism? The response, as paradoxical as the question, emerges as affirmative. The case of the authoritarian State Political Constitution in Portugal, drafted between 1930 and 1933, confirms this hypothesis. The document contains various principles and assumptions that draw their source from the innovations in the Weimar constitutional text produced in Europe at the beginning of the $20^{\text {th }}$ century, specifically those establishing references to the family, moral and economic corporations, the development of economic matters and the election of the president of the Republic by direct suffrage.

This article analyses how that German Constitution was received in Portugal and explores the grounds for the incorporation of its constitutional contents, associated with a modern democratic government, by a constituent power dedicated to establishing a new non-democratic state order. This correspondingly observes how, within this framework, there are three core questions: the first, that involves grasping just how the Weimar Republic, and in particular its 1920s Constitution, got perceived by politicians and jurists in Portugal; the second discusses which political and social problems the constituent legislator sought to address in 1933 in keeping with the consideration that this holds the key to understanding important aspects of the importing and adapting of Weimar constitutional facets by the political and juridical elites of the Estado Novo. Finally, the third question approaches the meaning of that which was termed the "constitutional movement" of the Portuguese $20^{\text {th }}$ century and thus discussing whether or not the 1933 Constitution introduced characteristics of political organisation in particular and the state in general that were then imposed through the discourse prevailing over this period and that still shape and influence the current democratic regime.

Palabras-chave: Weimar, Direitos económicos e sociais, Trabalho, Autoritarismo, Portugal

Keywords: Weimar, Economic and social rights, Labour, Authoritarianism, Portugal

\section{INTRODUÇÃO}

Num manuscrito intitulado "Constituição", datado de dezembro de 1931, Oliveira Salazar, então ministro das Finanças do Governo da Ditadura Militar em Portugal, liderado pelo general Domingos de Oliveira, registou esquematicamente apontamentos sobre: a) a estrutura, principios fundamentais e organização dos poderes do Estado da Constituição Política Portuguesa de 1911; b) as correntes jurídicas e políticas, mas também "as grandes posições da sociologia e da economia social" que enformavam as constituições europeias surgidas no pós I Guerra Mundial; c) os principios e a estrutura que deveriam nortear a nova Constituição em Portugal (a que veio a ser plebiscitada dois anos mais tarde, em 1933), destinada a dotar de nova legitimidade político-jurídica o regime estabelecido na sequência do golpe militar de 28 de Maio de 1926. Aí assinalou que a Constituição de 1911, a "última antes da guerra [I Guerra Mundial] e a 
última do tipo das constituições do século XIX", concebida na matriz do individualismo e do liberalismo, nascera "já atrasada em relação ao seu tempo". Destacava-lhe, na estrutura, o peso que assumiam as garantias individuais e a organização e competências dos poderes do Estado, notando que era omissa sobre "a família, as corporações morais e económicas, a opinião pública, o ensino e a educação nacional". Usando um estilo muito sintético, semelhante a uma sequência de itens, destinados possivelmente a desenvolvimento posterior, apontava que se tinha consagrado uma "república parlamentar e república simplesmente representativa", com "anulação do chefe de Estado" subordinado pela "origem e pela função ao poder legislativo", e com "insuficiência do poder executivo", que modificações posteriores àquele texto constitucional, feridas de "parcial inconstitucionalidade", não tinham conseguido corrigir, designadamente soluções tentadas de sobreposição do poder executivo ao legislativo em matéria financeira, por meio de leis ordinárias ("leis travões").

Sobre o constitucionalismo surgido depois de 1918, mostrava-se conhecedor do panorama europeu, destacando fenómenos como a generalização das repúblicas e a "colaboração dos juristas - Alemanha, Áustria -" na redação dos novos estatutos constitucionais, que lhe resultavam ser direcionados contra o "perigo bolchevista". Entendia que o poder legislativo continuara a ser reforçado pelo protagonismo das câmaras eleitas. Lamentava restrições ao poder executivo do presidente da república, verificando que "alguns corretivos" tentados, como "o princípio da dissolução, o princípio dos decretos leis, as restrições aos votos de desconfiança, o referendum para solver [sic] os conflitos entre os poderes", não haviam resolvido a "crise do Estado", que caracterizava como "fraqueza e instabilidade do poder". Anotava como reações a este cenário, correntes que promoviam: o "fortalecimento do presidente da República e do Governo e outorga dos direitos às corporações (Áustria) - Governos em ditadura parlamentar (com ameaça de dissolução" e o "Estado fascista e corporativo". Destacava como "uma novidade destas Constituições - o desenvolvimento do direito económico e social, ou misturado com disposições das garantias individuais ou em secção privativa (Weimar)", acrescentando que "foi-se em matéria económica até onde se podia ir, sem perigo de bolchevismo".

Feita essa análise, ponderava a divisão das matérias constitucionais a fazer no novo estatuto constitucional: "3 partes e as disposições complementares matérias de carácter económico e social - seu desenvolvimento e semelhança neste ponto a constituições como a de Weimar - mas não só muitos problemas têm aqui [no projeto de Constituição portuguesa] mais desenvolvimento e precisão, como a ordem das matérias é por si mais clara e superior àquela". Um pouco mais adiante, apontava que a estrutura do Estado contemplaria a "garantia das liberdades individuais e, agora também, dos grupos sociais e a defesa dos seus interesses fundamentais - as restrições daquelas por motivos de ordem social". Acrescentando que a "soberania (una) reside em a Nação (orgânica); a substituição da noção de poderes pela de órgãos: Pres[idente da] Rep[ública] Congresso - Governo - magistratura judicial; as instituições representativas; modo de formação dos órgãos - a independência na origem e na formação - $a$ harmonia recobra-se pela ação do chefe de Estado, órgão de soberania tão legitimo como o Congresso e por definição superior a ele, em certo modo; a impossibilidade do partidarismo". O manuscrito encerrava com um detalhe muito aproximado do 
que vieram a ser as partes da Constituição de 1933: parte I, dedicada às garantias fundamentais; parte II, relativa à organização política do Estado; parte III, formada por disposições complementares ${ }^{1}$.

Este documento, cuja análise detalhada se fará adiante, permite recriar o pensamento de Salazar sobre a abordagem que lhe mereceu o novo texto constitucional português, em preparação desde, pelo menos, o ano de 1930. Da documentação conhecida relativa ao dossier governativo da construção da futura Constituição de 1933, este é também um dos dois documentos de trabalho onde se regista a referência à Constituição alemã de 1919 como fonte para as disposições relativas à ordem económica e social. O outro documento é o "Relatório do Projeto de Constituição", publicado parcialmente no jornal Diário da Manhã, entre fins de Maio e Junho de 1931, produzido por Quirino de Jesus, advogado madeirense, colaborador do jovem ministro das Finanças, que por algum tempo o auscultou sobre a redação de alguma legislação em preparação, inclusive sobre o novo estatuto constitucional. Aî se lê que o texto constitucional weimeriano fez referência, a par da enumeração das liberdades e garantias pessoais, a outras "especialidades importantes, [...] representadas, principalmente, pelo direito social e económico, reflexo do espírito da democracia socialista, e por vários princípios relativos à família, à religião, ao ensino, às finanças e às comunicações" 2 . Por fim, num artigo daquele mesmo periódico, sobre a nova Lei Fundamental, encontra-se uma repetição da ideia presente no manuscrito de Salazar, a de que "o plano da Constituição Portuguesa que deixamos delineado não é cópia de nenhum outro, embora obedeça naturalmente a uma tendência já manifestada nas da Alemanha e da Áustria"3.

Tendo sido trazidas ao conhecimento do público em $2007^{4}$, estas três peças documentais permitem consolidar, com base empirica, interpretações que alguns constitucionalistas avançaram sobre as fontes da Constituição Politica portuguesa de 1933, notando afinidades do constitucionalismo do Estado autoritário em Portugal com a experiência constitucional de Weimar. Sem a preocupação de mencionar exaustivamente todos os estudos de direito constitucional que destacaram aquela influência alemã, registem-se os que foram pioneiros a estabelecer esse nexo e os que mais desenvolveram esse aspeto.

1 Arquivo Nacional da Torre do Tombo/ Fundo António Oliveira Salazar/ Correspondência Oficial/ Presidência do Conselho -5, Pasta 1, 29 de dezembro de 1933. Os itálicos são da autora deste artigo.

2 "Relatório do Projeto da Constituição", publicado em António de Araújo, A Lei de Salazar, Edições Tenacitas, Coimbra, 2007, p. 335.

3 Diário da Manhã, 22 de junho de 1931. Segundo António de Araújo, este artigo, e outros da mesma série dedicados à futura Constituição, tem a autoria de Quirino de Jesus.

4 O manuscrito de Salazar e o "Relatório do Projeto de Constituição" foram publicados, pela primeira vez, na obra de: António de Araújo, A Lei de Salazar, Lisboa, op. cit., pp. 121-128 e 329366, respetivamente. Nos estudos reunidos neste livro, Araújo discutiu o problema de a quem teria cabido a autoria do primeiro esboço da Constituição Política portuguesa de 1933, concluindo que a mesma coube a Quirino de Jesus. 
Um dos primeiros autores a sublinhar esse alinhamento foi Marcelo Caetano. O futuro sucessor de Salazar na chefia do Governo não detalhou, porém, em que aspetos do texto constitucional de 1933 prespassava essa influência. Foi mais claro sobre outras fontes da Constituição, como a própria experiência da Ditadura Militar, a que sublinhou dever-se a criação do que chamou uma "dupla presidência, da República e do Conselho [de Ministros], a tendência presidencialista e a da faculdade legislativa do Governo", bem como "o compromisso de formação de um regime corporativo" 5 . O seu simples registo sobre Weimar teve, no entanto, um curso longo, continuando gerações seguintes de professores de Direito e jurisconsultos a repetir, igualmente sem detalhar, a mesma afirmação. No final do regime, um dos seus assistentes, Miguel Galvão Teles, na lecionação de Direito Constitucional na Faculdade de Direito de Lisboa, ensinou a mesma premissa 6 .

Mais recentemente, o constitucionalista Vital Moreira reconheceu "influências secundárias da Carta Constitucional [portuguesa] de 1826, da Constituição de Weimar de 1919 e do sistema presidencial norte-americano" no texto constitucional português de 1933, enfatizando, todavia, que este foi o acordo possivel resultante da "luta de facções no quadro da ditadura militar" e um "produto original" do fundador do regime, Salazar. Também sem pormenorizar a que corresponderam tais influências, sublinhou que a forma de governo estava longe do modelo presidencial norte-americano, "visto que o Presidente da República não era o chefe do Executivo e a Assembleia não era independente do Presidente, pois este poderia dissolvê-la", e valorizou a eleição presidencial direta. Neste tópico, Moreira acentua que a forma de eleger por sufrágio direto o chefe de Estado "dava alguma congruência ao sistema em termos de legitimidade representativa", enquanto aquele foi, até à revisão constitucional de 1959 (ano em que a eleição passou para colégio eleitoral), um "representante direto dos cidadãos eleitores". Situou esta forma de eleição do presidente da República numa linhagem política estritamente portuguesa: a da experiência de eleição direta de Sidónio Pais (1917-1918) e da eleição do general Carmona, em 1928, na Ditadura Militar, instaurada pelo golpe militar de 28 de Maio de 1926. Quanto à chamada "constituição económica”, Moreira também não estabeleceu relação com Weimar, preferindo considerar o modelo corporativo português (que considerou ser o conjunto das disposições constitucionais, do Estatuto do Trabalho Nacional e outros diplomas estruturantes da organização corporativa, datados de 23 de setembro de 1933), como "manifestamente influenciado pela experiência fascista italiana"7.

\footnotetext{
${ }^{5}$ Marcelo Caetano, Constituições Portuguesas, 7. a edição, Editorial Verbo, Lisboa, 1994, p.108.

${ }^{6}$ Miguel Galvão Teles, Sumários desenvolvidos relativos ao título 2 da parte 3 do curso, direito constitucional português vigente, Associação Académica da Faculdade de Direito de Lisboa, Lisboa, 1970-1971, pp. 5 e ss.

7 Vital Moreira, "O sistema jurídico-constitucional do Estado Novo", en João Medina (edit.), História de Portugal. Dos tempos pré-históricos aos nossos dias, vol. XV, Ediclube, Amadora, 2004, pp. 409, 416-423.
} 
Também Jorge Bacelar Gouveia, ao enunciar as influências que a Constituição de 1933 recolheu de outros textos constitucionais, salientou a Constituição alemã de Weimar e a legislação do Estado fascista italiano; porém, o autor não especificou ${ }^{8}$.

Outra relação entre as duas constituições foi destacada pelo professor Diogo Freitas do Amaral, que optou por sublinhar como traço comum o facto de serem ambos textos programáticos, isto é, não possuírem um "conteúdo apenas jurídico-político, mas também económico, social e cultural", ainda que sem conter, necessariamente, um "programa de construção ou reconstrução nacional". Dentro deste género, estabeleceu, todavia, uma diferença entre aqueles dois textos constitucionais: enquanto que Weimar continha apenas preceitos avulsos para essa reconstrução, no texto português encontrava-se, na sua perspetiva, um projeto de sociedade, destinado à reforma das estruturas e das instituições. Neste sentido, encontrou maiores semelhanças entre as Constituições de 1933 e a da Áustria, outorgada em 1934, destacando que "transformaram o conservadorismo como ideologia num programa de reforma da sociedade, em certos aspetos um programa de progresso, noutros um programa de retrocesso" 9 . Este último exercício, porém, carece de alguma coerência, uma vez que a Constituição austríaca de 1934 não pode ser convocada para deslindar o problema das fontes da Constituição portuguesa de 1933, pois é-lhe posterior. A mesma questão se coloca com a muito aceite e difundida relação com a experiência italiana, que também não estava amadurecida nem terminada em 1933.

Correlação mais pormenorizada entre a Constituição alemã de 1919 e o texto constitucional português de 1933, foi estabelecida pelos constitucionalistas Jorge Miranda e J.J. Gomes Canotilho. Considerando que o traço mais original da Constituição de 1933 foi o corporativismo, "tomado como forma quer de organização social, quer de organização política, e ao qual se ajuntam elementos finalísticos", o professor Jorge Miranda sublinhou que tal ocorreu por influência "do integralismo lusitano, da doutrina social da Igreja, do socialismo catedrático e ainda da Constituição de Weimar"; apoiando-se, para elencar estas correntes doutrinais, no que escreveram alguns dos juristas e politicos contemporâneos de diferentes fases do próprio Estado Novo (no caso concreto, Marcelo Caetano, Mário de Figueiredo, Pedro Teotónio Pereira, José Pires Cardoso ou Soares Martínez). Destacando, numa atitude cautelosa, que somente a respeito dos diversos títulos, capítulos ou institutos se vislumbram inspirações e semelhanças da Lei Fundamental de 1933 com algumas Constituições estrangeiras, Miranda apontou, contudo, que "a intervenção do Estado na sociedade e na economia, a ordem administrativa e, muito provavelmente, a sistematização do texto constitucional denunciam a leitura [pelo legislador constituinte] da Constituição

8 Jorge Bacelar Gouveia, Manual de Direito Constitucional, vol. I - Teoria do Direito Constitucional, 6 ${ }^{\mathrm{a}}$ ed., Edições Almedina, Coimbra, 2016, p. 426.

9 Diogo Freitas do Amaral, “Corporativismo, Fascismos e Constituição”, en Fernando Rosas y Álvaro Garrido, Corporativismo, Fascismos, Estado Novo, Edições Almedina, Coimbra, 2012, pp. 94-97. 
de Weimar". Foi menos objetivo, para o sistema de governo de 1933, que defendeu dever qualificar-se de "representativo simples de chanceler" (e não como presidencial ou como um presidencialismo bicéfalo) e caracterizou como a pluralidade de órgãos governativos encoberta pela concentração de poderes no chefe de Estado, de quem dependiam quer a Assembleia Nacional quer o Governo (que ele nomeava e demitia livremente). Ainda que o presidente da República não governasse porque estava acompanhado de um Governo com competência própria e não pudesse agir sem o presidente do Conselho de Ministros, que referendava quase todos os seus atos e perante o qual respondiam todos os ministros. Enunciando, sem concretizar quais, que havia "pontos de contacto com Weimar", preferiu assinalar que eram mais fortes as afinidades com a Constituição imperial alemã de 1871, embora na Constituição portuguesa não se assumisse um puro sistema de chanceler ${ }^{10}$.

Debruçando-se sobre o sentido da regulamentação das atividades económicas e dos postulados que lhe assistiram e o enquadramento global dado à vida social na Constituição de 1933, outro destacado constitucionalista, J.J. Gomes Canotilho, sublinhou que o antiliberalismo da classe dirigente da ditadura salazarista encaminhou o legislador constituinte para encarar, "como já tinha feito a Constituição de Weimar, a transformação da base social do liberalismo e a evolução do capitalismo de concorrência”. A essa luz, sustentou, aquele texto constitucional incluía um "bloco de artigos consagrados ao capitalismo organizado, onde se definem os principios da coordenação e regulamentação da vida económico-social (constituição económica)", aos quais, argumentou, "se apontam infundadamente laivos do socialismo catedrático". Com esta última crítica, sustentada no reparo de que na Lei Fundamental de 1933 foi feita uma "drástica redução dos direitos fundamentais dos trabalhadores (proibição do direito à greve, proibição da liberdade sindical), em contraposição com as liberdades reconhecidas ao outro parceiro social", visou fundamentalmente posições sustentadas por Marcelo Caetano ${ }^{11}$, e por extensão daqueles que até à atualidade continuaram(am) a secundar o eminente jurista, sem o necessário distanciamento que, metodológica e epistemologicamente, exige ser tomado quando se absorve a análise daquele que pode ser considerado o principal ideólogo do regime estadonovista (faceta que construiu, sobretudo, enquanto jusriconsulto e professor da Faculdade de Direito de Lisboa). É curioso notar como, apesar das interpretações de Miranda e Canotilho, os estudos sobre constituição económica em Portugal, ao abordarem o caso do texto constitucional

10 Jorge Miranda, Manual de Direito Constitucional, tomo I, 2. ${ }^{\text {a }}$ edição revista, Coimbra Editora, Coimbra, 1982, pp. 258, 259, 270 e 271. Nas versões posteriores deste manual, o autor manteve esta apreciação.

11 J. J. Gomes Canotilho, Direito Constitucional e Teoria da Constituição, 3. ${ }^{a}$ edição, Coimbra, Edições Almedina, Coimbra, 1999, pp. 177-178. Veja em particular a referência a Marcelo Caetano, na nota de rodapé 74 . 
de 1933, evitaram caracterizar quer influências, quer afinidades ou diferenças face a restantes experiências constitucionais ${ }^{12}$.

Nesta ponderação da literatura existente, cumpre ainda acrescentar que no domínio da história também não foi, até ao momento presente, analisada a receção em Portugal da experiência de Weimar, ao contrário do que tem sucedido em vários outros países europeus, que têm explorado com fulgor dimensões variadas dessa influência, designadamente nos domínios da cultura e das artes. Esta falta de investimento que se pode observar no tema, para o período que seria o das décadas de 1920 até, pelo menos, ao pós-II Guerra Mundial, no final dos anos de 1940 e ao longo do decénio de 1950 (como sucedeu em diversos países europeus, particularmente naqueles que se democratizaram e que recuperaram Weimar nas novas constituições que erigiram, recolocando dessa forma aquela experiência constitucional novamente em discussão), não deixa de ser intrigante e constituiu o problema inicial que estrutura este artigo. Se houve, como atestam documentos da preparação da Constituição de 1933, contacto e assimilação da experiência constitucional alemã de 1919, por parte dos juristas e políticos portugueses, porque motivo sabemos tão pouco sobre esse fenómeno que se pode incluir na chamada categoria de "processos transnacionais de difusão constitucional", no caso concreto, ocorrido na Europa de Entre Guerras? Julgo que a principal razão para tal reside na dificuldade em conceber e explicar como uma experiência constitucional democrática influiu e foi, em certa medida, recuperada no âmbito de um constitucionalismo gerado por um poder autoritário. Neste estudo, pretende-se iluminar que circuito de ideias pode ter ocorrido para se chegar a tal resultado, por um lado, e detalhar, explicando porquê, quais os conteúdos constitucionais de 1933 onde a influência weimeriana parece evidente, por outro lado. Debatem-se, para tanto, três questões: a primeira, que envolve saber como foi percebida a República de Weimar e em particular a sua Constituição, na década de 1920, em Portugal; a segunda, que discute quais os problemas politicos e sociais a que pretendeu responder o legislador constituinte de 1933, considerando que aí reside a chave para entender aspetos de importação e de adaptação do fenómeno constitucional weimeriano pelas elites políticas e jurídicas do Estado Novo; por fim, a terceira questão que indaga sobre o sentido do que aqui chamo "movimento constitucional" do século XX português, discutindo se a Constituição de 1933 introduziu ou não características da organização política, em particular, e do Estado, em geral, que se impuseram no decurso dessa temporalidade e que ainda marcam o atual regime democrático. Por "movimento constitucional" entendo o conjunto de ideias e de esforços, desenvolvidos pelo legislador constituinte em diálogo e em negociação (formal e informal) com a diversidade de atores que compõem a sociedade (e em especial os que têm poder decisório sobre o sentido da coisa pública), capazes de determinar uma matriz identitária (diretamente relacionada com a principal transformação que uma Constituição projeta trazer ao Estado e à sociedade) para os textos constitucionais. Envolve um tempo de transição, sem limites rígidos, que, e por

12 Um exemplo encontra-se em: Guilherme de Oliveira Martins, Lições sobre a Constituição Económica Portuguesa, vol. 1, Associação Académica da Faculdade de Direito de Lisboa, Lisboa, 1984, p. 24. 
consequência, não pode coincidir com delimitações cronológicas dos próprios periodos constituintes. Donde, implica atender a germinações e ajustes do direito, produzidos no tempo longo, por via das permanências que vão sendo fixadas e que, uma vez introduzidas, podem sofrer arranjos normativos diversos, mas não resultam na sua substituição total. Implica também atender às influências externas que permeiam uma sociedade e que se introduzem também no direito, afetando o seu itenerário.

\section{WEIMAR RECEPCIONADA PELA REPÚBLICA PORTUGUESA (1919-1926)}

Ao contrário do que se poderia imaginar, a experiência politica e constitucional da República de Weimar não foi objeto de atenção do periodismo jurídico português, onde não se encontram notícias sobre a Constituição alemã de 1919 nem sobre os respetivos trabalhos constituintes. Também a pesquisa realizada sobre discursos e escritos de dirigentes políticos do republicanismo português, direcionada em especial para propostas de revisão da Constituição de 1911 e para os projetos de novos textos constitucionais, apresentados até 1926, reflete um total alheamento da experiência weimeriana ${ }^{13}$.

Terão sido, sobretudo, dois os factores principais que impediram nos anos mais próximos a 1919, qualquer acolhimento dos referenciais do constitucionalismo de Weimar. Por um lado, a profunda instabilidade da vida política portuguesa (marcada pela decomposição do Sidonismo e formação de novos Ministérios, e pela necessidade de respostas a uma aguda crise social e financeira), cruzada com inéditos esforços diplomáticos a desenvolver na cena internacional (suscitados pela participação de Portugal na Conferência da Paz e, muito especialmente, pelo papel que o país deveria desempenhar na futura Sociedade das Nações, que, refira-se en passant colocaram a descoberto o estado das relações entre Portugal e vários países e produziram alterações nas lideranças e no peso de alguns partidos políticos na cena política interna ${ }^{14}$ ). Por outro lado, a percepção generalizada entre a classe politica dirigente em Portugal da fragilidade da Alemanha, enquanto grande derrotada da I Guerra Mundial. As circunstâncias dificultavam a apreciação do modelo político da Alemanha, ele próprio atravessado pelo signo da recomposição. As relações com aquele país estavam subordinadas a dois aspetos concretos: um, a renovação e intensificação do relacionamento económico com aquele paîs (na linha da estratégia seguida por Inglaterra), procurando-se firmar um novo acordo comercial; outro, o problema da política de reparações e devoluções de material sequestrado durante a I Guerra Mundial15.

13 Luís Bigotte Chorão, A Crise da República e a Ditadura Militar, Sextante Editora, Lisboa, 2009, pp. 373-378 e 527-553; Id., Politica e Justiça na I República, vol. 2 (1915-1918), Letra Livre, Lisboa, 2018, pp. 7-19 e 66-77.

14 José Medeiros Ferreira, Portugal na Conferência da Paz. Paris, 1919, Quetzal Editores, Lisboa, 1992, pp. 49-60, 81-86.

15 Para mais informação sobre estes aspetos das relações entre Portugal e a Alemanha, consulte-se: Lina Alves Madeira, Alberto da Veiga Simões. Esboço biográfico, Quarteto, Coimbra, 2002 . 
As observações, para o período de 1922 a 1923, do embaixador destacado para a legação portuguesa em Berlim, o ex-ministro dos Negócios Estrangeiros no Governo saído do Outubrismo de 1921, Alberto da Veiga Simões, fornecem um impressivo relato da degradação acelerada das condições políticas, sociais e económicas alemãs ${ }^{16}$. $\mathrm{Na}$ sua correspondência assinalou a progressão dos "nacionalistas" (do Partido Popular Nacional Alemão - Deutcshnationale Volkspartei) no campo político, a propósito das eleições para a presidência do Reich, ganhando espaço contra centristas e socialistas, apesar da falta de entusiasmo que com que foi acolhida a candidatura do marechal Hindenburg17; a difícil recomposição económica e financeira da Alemanha, em esforço para manter o alargamento da sua produção industrial e suportar, paralelamente, a desvalorização da moeda e o cumprimento da política de reparações ${ }^{18}$; a resiliente adaptação da economia alemã ao tratado de Rapalo (1922), em circunstâncias de maior vulnerabilidade após o fracasso da estratégia de Inglaterra para a política de reparações e para as relações com a Rússia19; o aumento da conflitualidade laboral e social em torno das 8 horas de trabalho, ameaçadas por propostas partidárias que defendiam, face à urgência de defender o marco da desvalorização sucessiva, a necessidade de intensificar a produção (em contraproposta ao plano de garantia das divisas com o ouro do Reichsbank) ${ }^{20}$; a crescente tensão entre o Governo alemão e a Polónia, em consequência da expulsão de polacos e alemães dos respetivos territórios ${ }^{21}$; a falta de popularidade da experiência federalista, 0 retorno à ideia de separação em vários Estados alemães, inclusivamente dando origem ao surgimento de movimentos separatistas e à proclamação da República Renana ${ }^{22}$; as tensas relações entre o presidente Ebert e o seu chanceler e a generalização da discussão pública sobre a eficácia (ou falta dela) dos arranjos

16 Até 1922, são muito parcas as informações diplomáticas produzidas no âmbito da legação portuguesa em Berlim; essa situação sofre uma significativa alteração nos anos de 1922 e 1923 , correspondentes aos anos em que Veiga Simões ocupou funções.

17 Arquivo Histórico do Ministério dos Negócios Estrangeiros (AHMNE), Legação de Portugal em Berlim (1919-1932), Cx. 17, A-37: Ofício do embaixador Veiga Simões para o ministro dos Negócios Estrangeiros, datado de 14 de Outubro de 1922.

18 AHMNE, Legação de Portugal em Berlim (1919-1932), Cx. 17, B-59: Ofício do embaixador Veiga Simões para o ministro dos Negócios Estrangeiros, datado de 24 de Outubro de 1922.

19 AHMNE, Legação de Portugal em Berlim (1919-1932), Cx. 17, B-95 e B-102: Ofícios do embaixador Veiga Simões para o ministro dos Negócios Estrangeiros, datados respectivamente de 4 e 11 de Dezembro de 1922.

20 AHMNE, Legação de Portugal em Berlim (1919-1932), Cx. 17, A-40 e B-80: Ofícios do embaixador Veiga Simões para o ministro dos Negócios Estrangeiros, datados respetivamente de 1 e 9 de Novembro de 1922.

21 AHMNE, Legação de Portugal em Berlim (1919-1932), Cx. 17, A-28: Ofício do embaixador Veiga Simões para o ministro dos Negócios Estrangeiros, datado de 11 de Agosto de 1923.

${ }^{22}$ AHMNE, Legação de Portugal em Berlim (1919-1932), Cx. 17, B-331, B-640 e A-135: Ofícios do embaixador Veiga Simões para o ministro dos Negócios Estrangeiros, datados respetivamente de 8 de Maio, 26 de Outubro de 1923. 
constitucionais em função das soluções políticas que se pretendiam alcançar ${ }^{23}$. $\mathrm{Na}$ leitura de Veiga Simões, a Constituição alemã de 1919 agudizava as dificuldades da governação em matéria económica e financeira, ao obrigar o Parlamento ou o Chefe do Governo, mesmo em uso de plenos poderes, a consultas diversas aos representantes das forças politicas, que determinavam que as providências adoptadas fossem sempre tardias. Não tinha dúvidas que, na Constituição, que dizia "dominada pela ideologia marxista", "reside a essência do mal, e a verdadeira causa, ainda não vista do outro lado do Reno, da situação alemã", pois onde "o poder se dispersa em vários braços, não é fácil a um governo mandar, mesmo com boa cabeça e bons músculos para isso". Categórico, Veiga Simões concluía: "mais do que as consequências do Tratado de Versalhes, o caos alemão provém da ideologia da Casa Branca temperada a equações surannées de Marx"24.

\subsection{O estudo da Constituição alemã de 1919 na disciplina de Economia Social}

Foi através do curso de Direito das Faculdades de Coimbra e Lisboa que, em Portugal, se introduziu a leitura da Constituição alemã de 1919 e se promoveu a reflexão sobre essa experiência constitucional. A sua recepção foi favorecida no quadro da disciplina (semestral) de Economia Social, autonomizada da disciplina de Economia Política (criada, na Universidade de Coimbra, em 1836) pela reforma do ensino de 1911, que aumentou o peso das Ciências Económicas nas Faculdades de Direito ${ }^{25}$.

No terceiro ano do curso jurídico de 1928-1929, já em plena Ditadura Militar, o professor João Pinto da Costa Leite (Lumbralles), futuro subsecretário de Estado das Finanças (1934-1937) e das Corporações e Previdência Social (1935-1936) e ministro de várias pastas dos Governos de Salazar entre 1937 e 1955, ensinava naquela disciplina, ministrada na Faculdade de Direito de Lisboa, as soluções que, durante o conflito bélico mundial de 1914-1918 e após o seu

23 AHMNE, Legação de Portugal em Berlim (1919-1932), Cx. 17, A-28 e A-137: Ofícios do embaixador Veiga Simões para o ministro dos Negócios Estrangeiros, datados respetivamente de 21 de Outubro de 1922 e 10 de Novembro de 1923.

${ }^{24}$ AHMNE, Legação de Portugal em Berlim (1919-1932), Cx. 17, A-137: Ofício do embaixador Veiga Simões para o ministro dos Negócios Estrangeiros, datado de 10 de Novembro de 1923.

25 Pode admitir-se que também na disciplina de Direito Público tenha sido apreciada a Constituição alemã de 1919. A pesquisa realizada sobre os sumários desta disciplina, ministrada na Faculdade de Direito de Lisboa, não foi conclusiva, porque os mesmos são demasiado esquemáticos e não detalham o que foi estudado sob o ponto designado "caso alemão". É importante salientar que o estudo do constitucionalismo de Weimar não representaria uma singularidade. Da consulta dos sumários e manuais de diversas disciplinas constata-se que a metodologia habitualmente seguida, em Coimbra e em Lisboa, era a de apresentação de doutrinas e suas aplicações, matérias legislativas de outros países e seu confronto com as soluções portuguesas. Em Direito Público, desde a criação da disciplina, foi estudada a organização política dos Estados, especialmente em Inglaterra, França, Espanha, Itália, Áustria, Bélgica, Alemanha, Estados Unidos da América e Brasil. Cf. Marnoco e Sousa y Alberto dos Reis, A Faculdade de Direito e o Seu Ensino, F. França Amado Editor, Coimbra, 1907, p. 28. 
fim, ao longo da década de 1920, se tinham tentado incrementar por toda a Europa para resolução da chamada "questão social". Aî, Costa Leite ensinava também, dentro do que classificava como experiências modernas de "tendência neo-corporativa", as inovações trazidas pelo capítulo V da Constituição de Weimar, "onde se traça e organiza constitucionalmente a nova estrutura económica da Alemanha". Para o jovem professor, os eixos mais interessantes assentavam na possibilidade, criada pelo art. ${ }^{\circ} 156 .^{\circ}$, de habilitar o "governo alemão [a Confederação] a intervir quase discricionariamente na organização da vida económica do seu país; no estímulo à organização profissional, feito no art. ${ }^{\circ}$ 159..$^{\circ}$, na criação de instituições de seguros e previdência social, determinada pelo art. $^{\circ} 161 .^{\circ}$; e, finalmente, o que classificava de "mais importante", o art. ${ }^{\circ}$ $165 .^{\circ}$, que interpretava como estabelecendo uma "estrutura de organização trabalhista oficializada", lançando as "bases de um sistema económico em que a harmonia entre empresários e trabalhadores é tentada pela estrita colaboração das suas classes que nos conselhos se apresentam revestidas dos mesmos direitos". Destacava ainda a criação dos Conselhos Económicos (os Territoriais e o Federal) pelo legislador de Weimar, que reuniam representantes das organizações patronais e de trabalhadores. Das quatro experiências que trataria - Holanda, Alemanha, Espanha e Itália - mostrava aderir especialmente às soluções alemãs. Considerava a experiência holandesa tentada pelo partido católico um fracasso, repudiando inclusivamente a confessionalidade que permeava a estrutura erigida; sobre a experiência espanhola era exaustivo na descrição, mas parco na apreciação; por fim, não se mostrava seduzido pela organização corporativa do fascismo italiano, possivelmente por lhe encontrar uma "base essencialmente política, visto que apresenta, tanto no seu aspeto orgânico, como ainda na sua atividade funcional a marca inconfundivel do fascismo". Apreciava, no entanto, a criação da magistratura do trabalho e a proibição do lock-out e das greves. Maior empatia tinha pela experiência corporativa tentada pela República de Carnaro, com Gabriel d'Anunzio, em especial pela sua proposta bicameral para a organização parlamentar (uma câmara eleita por sufrágio individual, outra pelas corporações) ${ }^{26}$.

Esta abordagem é significativa por vários aspetos que cumpre destacar. A leitura e a recepção do constitucionalismo weimeriano articulou-se estreitamente com a procura de soluções para os principais problemas que se colocavam em Portugal nas primeiras três décadas do século XX. Um desses problemas era a "questão social" e, daí, o seu tratamento na disciplina de Economia Social, que funcionava, para usar uma expressão da atualidade, como um "observatório", onde se analisavam experiências incrementadas. Entre 1913-1919, por exemplo, a disciplina foi dominada por extensos comentários às experiências europeias, habitualmente descritas sob o título "Internacionalização do direito operário", apresentando-se leis de proteção do trabalho, dos seguros sociais e dos acidentes de trabalho, ou ainda regimes jurídicos das convenções coletivas de trabalho,

26 Belmiro Pereira, Economia Social. Segundo o plano das prelecções do Ex.mo Sr. Doutor João Pinto da Costa Leite (Lumbrales) ao curso do 3. ${ }^{\circ}$ ano jurídico (1928-1929), Livraria Atlântida, Coimbra, [1929], pp. 44-47 e 70-102. 
inexistentes em Portugal ${ }^{27}$. A busca de novas soluções completava a abordagem metodológica. Tratava-se de uma dinâmica normalizada, na época, uma vez que o direito vinha sendo considerado (por influência das diversas correntes sociológicas) um processo natural da vida das sociedades e, portanto, participante da sua (re)construção ${ }^{28}$. O outro problema era o da crise do sistema parlamentar, que punha em causa a legitimidade do sistema e impunha a ideia de uma falta de alternativas válidas de governação. Se esta era uma discussão que, com propriedade, cabia no Direito Público, relacionava-se estreitamente com todos os outros domínios da ciência jurídica. Não admirando, como tal, que, na própria Economia Social, se tivesse feito, em Portugal, um caminho no sentido da defesa de um Executivo forte, organizador do exercício das liberdades públicas e da própria atividade do poder legislativo.

\section{A ECONOMIA SOCIAL E AS TRADIÇÕES E MODERNIZAÇÕES DO DIREITO E DO TRABALHO NA EUROPA}

A institucionalização nas Faculdades de Direito da disciplina de Economia Social, que o seu primeiro docente em Coimbra, Marnoco e Sousa, apresentava como "o estudo da condição da classe trabalhadora e das instituições destinadas a melhorar e transformar essa condição"29, surgira após um período de interesse pelo movimento operário (que conduzira a empenhamentos muito diversificados, quer na doutrina, quer na prática, por exemplo, em defesa do cooperativismo e do mutualismo, ou da educação popular, ou da livre associação) e, em particular, pela legislação protectora do trabalho fabril ${ }^{30}$. Esse interesse é observável nas lições de Economia Política, bem como nos temas das dissertações dos estudantes e em estudos preparados por alguns dos docentes e economistas mais prestigiados, como Fernando Emídio da Silva e o próprio Marnoco e Sousa ${ }^{31}$. Uma

\footnotetext{
27 Fernando Emídio da SILVA, Economia Social: sumário das lições magistrais e dos assuntos dos exercícios práticos. Ano de 1913-1914, s.a.1. 1914; José C. da SILVA, Economia Social. Apontamentos coligidos de harmonia com as prelecções feitas pelo Exmo. Sr. Dr. Carneiro Pacheco ao curso do $3 .^{\circ}$ ano de 1914-1915, Tipografia Operária, Coimbra, 1915, pp. 35-36, 264-265.

28 Marnoco e Sousa y Alberto dos Reis, A Faculdade de Direito e o Seu Ensino, op. cit., p. 8.

${ }_{29}$ Marnoco e Sousa, Tratado de Economia Politica, vol. I, F. França Amado Editor, Coimbra, 1917 , p. 55.

30 Paulo Merêa, "Esboço de uma História da Faculdade de Direito", Boletim da Faculdade de Direito, n. ${ }^{\circ}$ XXIX, 1953, pp.121-122; Bernardo G. Lobo Xavier, Curso de Direito do Trabalho, 3. ${ }^{a}$ ed., Editorial Verbo, Lisboa, 2004, p. 89; Carlos Bastien, J. Frederico Laranjo, Principios de Economia Politica (1891), Banco de Portugal, Lisboa, 1997, p. XIII.

${ }^{31} \mathrm{Da}$ produção registada entre 1905 e 1915, refiram-se alguns exemplos: L. Gonçalves, A evolução do movimento operário em Portugal (Coimbra, 1905); F. Emídio da Silva, O operariado português na questão social (Coimbra, 1905); R. Ennes Ulrich, Legislação operária portuguesa (Coimbra, 1906); F. Emídio da Silva, As Greves (Coimbra, 1912); Idem, Acidentes de Trabalho (Lisboa, 1913); B. de Magalhães, Seguro contra Acidentes de Trabalho, (Lisboa, 1913); Marnoco e Sousa, Caracteres da legislação operária (Coimbra, 1914-1915); Ferreira Borges, Estudo da Legislação Portuguesa sobre Acidentes de Trabalho (Lisboa, 1915). Alguns desses trabalhos refletiam a influência da corrente da economia politica nacional, ensinada especialmente pelo professor Abel de Andrade, que explorava elementos estatísticos, demográficos e históricos para a caracterização das instituições económicas portuguesas. Anos depois, entre 1931 e 1935, um
} 
vez institucionalizada, aquela disciplina tornou-se uma importante plataforma de divulgação da escola intervencionista (alemã, em particular, com acompanhamento dos trabalhos de Wagner e Schomoller). Embora tenha falecido prematuramente em 1916, Marnoco e Sousa alcançou cultivar aí (bem como nas várias disciplinas que lecionou) uma doutrina sobre a ação do Estado, que encontrou, em certos aspetos, materialização no projeto político e económico dos fundadores do Estado Novo (muitos dos que, formados em Direito, integraram, depois de 1930, cargos governativos e produziram legislação, haviam sido seus alunos; Salazar foi, inclusivamente, seu assistente). Tal correspondeu à posição de que o Estado deveria buscar um meio termo entre o individualismo e o socialismo, para, sem exercer uma ingerência absorvente, promover o desenvolvimento económico e moral da sociedade; e gerou uma sensibilidade crescentemente positiva ao intervencionismo estatal na contenção da concorrência social e na coordenação dos agregados sociais e económicos, e à defesa da representação de interesses sociais.

$\mathrm{Na}$ realidade, e olhando para lá da influência direta de Marnoco e Sousa, um tempo longo no ensino do Direito tinha permitido aprofundar o estudo dos fenómenos económicos e, sob orientação de várias escolas, suplantar a influência da reflexão liberal de indole económica (abordada inicialmente com recurso a Adam Smith e, já depois de 1900, com foco na escola austríaca). Primeiro, fora introduzida a escola socialista (estudando-se desde Fourier, Saint-Simon, Proudhon, Marx, Lassalle e Wallace), passando mesmo pela sua forma sociológica (com Spencer, até Bernstein e Kautsky). Depois, fora a escola histórica alemã (que, nas duas últimas décadas do século XIX, tivera List como referência). Também as tendências no ensino da ciência politica, a partir de 1900, orientadas pelas doutrinas da escola histórica, com grande acolhimento do evolucionismo crítico de Herbert Spencer (novamente, por exemplo, em Marnoco e Sousa), conjugadas com a aproximação à psicologia social, haviam produzido novos fundamentos sobre os conceitos de Estado, de soberania e de sociedade politica, porventura reforçados com a renovação dos estudos de administração pública assente no socialismo catedrático e em alguma doutrina italiana (Messedaglia, Morpurgo e Ferraris) ${ }^{32}$. No Direito Público, em meados da década de 1910, as teses do institucionalismo francês (Léon Duguit), introduzidas em grande medida por Domingos Fezas Vital, haviam modificado a classificação das funções

pique de semelhante produção voltou a registar-se, com a elaboração de várias monografias regionais e profissionais, na disciplina de Economia Social, regida por Albino Vieria da Rocha na Faculdade de Direito de Lisboa, para o curso de Método da Ciência Social, ministrado, pela primeira vez no ano letivo de 1931-1932, por Paul Descamps, que aí seguiu as ideias de Le Play e Tourvilee. Cf. Marcelo Caetano, Apontamentos para a História da Faculdade de Direito de Lisboa, Universidade de Lisboa/ Faculdade de Direito, Lisboa, 1961, p. 112; Marnoco e Sousa y Alberto dos Reis, A Faculdade de Direito e o seu ensino, op. cit., pp. 16-19, 89-91.

32 Marnoco e Sousa y Alberto dos Reis, A Faculdade de Direito e o Seu Ensino, op. cit., pp. 19, 24-36. 
jurídicas do Estado. Menor influência, mas com presença significante no ensino em Lisboa, teve o decisionismo de Carl Schmitt ${ }^{33}$.

Uma tal evolução é identificável nas soluções que os professores de Economia Social, em Coimbra e em Lisboa, vão tecendo como possíveis para Portugal, para uma nova organização política, social e económica, podendo encontrar-se diferenças significativas entre propostas feitas até 1915 e outras posteriores, apresentadas a partir de 1928. No próprio Marnoco e Sousa se encontram, aliás, ideias que viabilizam transições de um modelo liberalindividualista a outro socializador. Situando-se ainda num quadro em que a propriedade e a liberdade de trabalho eram os fundamentos da ordem económica das sociedades, e as relações laborais eram entendidas dentro do paradigma contratualista, Marnoco recolheria de Duguit outra visão, a de que todo o indivíduo tem obrigação de realizar na sociedade uma certa função em harmonia com o lugar que aí ocupa, que o fará acolher uma ideia social de propriedade e de liberdade do trabalho. Como tal, o direito de propriedade perdia o seu carácter sagrado e inviolável para dever estar em harmonia com os interesses gerais da sociedade, sendo defensável a intervenção do legislador "no sentido de estabelecer neste direito as restrições conformes às necessidades sociais a que corresponde tal instituto". Também recusaria a liberdade de trabalho absoluta, porque não existiam direitos individuais absolutos, para lhe redescobrir, através ainda de Duguit, uma "função social, isto é, a obrigação que cada um tem de desenvolver a sua atividade como elemento da vida social". Reconhecia, não obstante, o direito à greve como manifestação da liberdade de trabalho e aplaudia a sua consagração na legislação portuguesa (decreto de 6 de dezembro de 1910), que permitira que Portugal pudesse "entrar no grémio das nações verdadeiramente civilizadas". $\mathrm{Na}$ controvérsia entre intervencionistas sobre a legitimidade do legislador para regulamentar o trabalho, posicionou-se pela parcial intervenção do Estado, com o argumento de que este "não pode deixar de se preocupar com a vida, a saúde e a liberdade humanas, compreendendo-se assim perfeitamente a sua ação nesta matéria"34.

Intuía ainda Marnoco e Sousa que a nova legislação europeia sobre a organização do trabalho "se afasta dos principios tradicionais do direito civil", e previa que, futuramente, as diferenças entre legislações nacionais desaparecessem, devendo caminhar-se para uma "analogia", que, notava, estava a ser favorecida por congressos internacionais, pelo ensino e pelas "publicações de legislação operária, cada vez em maior número". Atento ao movimento codificador europeu, notava, no ano letivo de 1913-1914, que a principal mudança residira na transformação do contrato de trabalho individual para coletivo, e na abertura ao reconhecimento da personalidade dos sindicatos. Mostrava simpatia pelos códigos de trabalho em formação e, entre as duas orientações que lhes apontava como possiveis, a socialista e a intervencionalista,

33 Rui Chancelere de Machete, Estudos de Direito Público e Ciência Politica, Fundação Oliveira Martins/Centro de Estudos Administrativos, [s.1.], 1991, pp. 12-19.

34 Marnoco e Sousa, Constituição Politica da República Portuguesa. Comentário, Imprensa Nacional/ Casa da Moeda, Lisboa, 2011, pp. 127-138. 
preferia a segunda por ser menos radical e colocar "nas mãos do Estado a solução dos conflitos operários". Admirava o Código Imperial dos Seguros (Reichs versichérnungs ordnung), publicado na Alemanha em 19 de junho de 1911, pelo alargamento de seguros às diferentes classes trabalhadoras, mas considerava-o um grande encargo para o Estado, que não poderia ser levado mais longe. Admitia o atraso dos "países latinos" em matéria de legislação laboral, com escassa regulamentação sobre o trabalho das mulheres e dos menores e sobre higiene e segurança nas fábricas. Se valorizava o exemplo dos Estados Unidos da América pela fiscalização que se exercia sobre a aplicação da legislação sobre o trabalho e também pela tendência para a arbitragem, mais apreciava o que sucedia na Alemanha, Áustria, Hungria e Suiça, onde encontrava uma "síntese admirável dos direitos de proteção ao operário". Sobre a ação sindical, considerada para defesa dos interesses profissionais, tinha uma posição hostil, dirigida sobretudo ao que classificou de "sindicalismo revolucionário" e à ideia de federações de sindicatos, que gradualmente foi modificando em sentido mais favorável, compaginando-a com a sua posição de base: a valorização do princípio da liberdade de associação, dele emanando o princípio do alargamento das funções económicas do Estado, com subordinação a ambos da liberdade económica individual ${ }^{35}$.

Na segunda metade da década de 1910 será possivel identificar uma assumida preferência de alguns professores, como Carneiro Pacheco (futuro ministro da Instrução e, mais tarde, da Educação, nos anos de 1936-1940), Fernando Emídio da Silva, Albino Vieira da Rocha ou Martinho Nobre de Melo, por um ecletismo doutrinal, firmado a partir de propostas recebidas das escolas intervencionistas. Considerava-se necessária a intervenção do Estado, sem recear que pudesse contrariar a liberdade de trabalho e a "acção da associação livre". Daí admitir-se o auxílio dos poderes públicos às instituições sociais, consideradas eficazes no melhoramento da situação das classes trabalhadoras (associações de socorros mútuos, cozinhas económicas, habitações económicas, seguros sociais), e a defesa da ideia de submeter todas as categorias de trabalhadores a uma regulação uniforme, apresentando como exemplos de sucesso, os casos da Alemanha e também de Inglaterra. Outra evolução desejada era a da regulamentação legal das convenções coletivas de trabalho, entendidas como meio para "evitar abusos da parte das associações". Prevalecendo, todavia, um regime de liberdade contratual, não se equacionava a extensão das convenções coletivas aos operários não sindicalizados, a fim de se salvaguardar a posição dos empregadores que, em tais circunstâncias, ficariam "inibidos de recorrer aos serviços dos operários toda a vez que não quisessem sujeitar-se às imposições dos sindicatos" 36 .

35 Ambrósio Neto, Martinho Simões y José Fortes, Apontamentos de Economia Social coligidos em harmonia com as preleções do Dr. Marnoco ao curso de 1913-1914, Livraria Neves Editora, Coimbra, 1914; Maria de Fátima Sá Silva Brandão, "Introdução", en Marnoco e Sousa, Ciência Económica: Prelecções feitas ao curso do segundo ano de 1909-1910 (1910), Banco de Portugal, Lisboa, 1997, pp. XXXIV-XXXV.

36 José C. da Silva, Economia Social. Apontamentos coligidos de harmonia com as prelecções feitas pelo Ex.mo Sr. Dr. Carneiro Pacheco ao curso do 3. ${ }^{\circ}$ ano jurídico de 1914-1915, op. cit. , pp. 21 
Algumas tendências de organização dos trabalhadores, como o cooperativismo, foram defendidas por professores, como Fernando Emidio da Silva, que revelou particular simpatia por uma das escolas intervencionistas: a solidarista, de base comteana, considerando a ideia da interdependência orgânica como a base da vida social ${ }^{37}$. Com as suas posições engrossou um meio termo entre individualismo e socialismo, em expansão por estes anos, na academia portuguesa e nos círculos políticos. Por exemplo, no tratamento que dispensou à figura do trabalhador manifestava-se um reconhecimento da emergência de novos direitos ao trabalhador, a nivel individual, e à associação, a nivel coletivo; porém, àqueles continuava a sobrepôr uma noção do Estado tutelar, simultaneamente protector e vigilante das ações desses sujeitos.

Até meados da década de 1920, pode-se sustentar que os juristas portugueses não romperam com as noções do "direito social pré-bélico", para recuperar uma expressão de Otto Kahn-Freund no seu escrito "A mutação da função do direito do trabalho" (1932) 38 . Com efeito, permaneceu um entendimento do prestador de trabalho como contraente isolado (no Código Civil de 1867, que então vigorava, a prestação de serviços, como era entendido o trabalho, era regulada apenas por 5 artigos), objeto de tutela e assistência da parte do Estado ou do dador de trabalho. Essa proteção, dispensada a nível individual, perdia-se perante a atividade coletiva dos trabalhadores. Esta continuou a implicar manifestações de ordem e de autoridade (através da polícia e da própria aplicação do direito penal, tendo conduzido, por exemplo, a prisões e deportações sem julgamento de dirigentes sindicalistas para as colónias africanas; daí o epíteto de "Racha sindicalistas" com que foi designado Afonso Costa, chefe do Governo Provisório e de outros Ministérios, nos anos de 19131914, 1915-1916 e 1917). Também a normatividade que se construiu para a disciplina do trabalho (horário de trabalho e descanso semanal; higiene, salubridade e segurança no trabalho; ampliação do regime de acidentes de trabalho; proteção em doenças profissionais) não foi alheia a um propósito de inculcação no trabalhador de um sentimento de pertença à comunidade organizada pelo Estado, progressivamente mais centralizador. Por essa razão, o redescobrimento da dimensão coletiva pelo trabalhador, a sua movimentação como parte de uma classe, embora caminhasse para uma realidade cada vez mais organizada, foi restringida. A contratação coletiva não alcançava outro significado do que uma simples estipulação de um contrato de direito privado. A melhoria da

e ss.; Fernando Emydio da Silva, Albino Vieira da Rocha, Martinho Nobre de Melo, Economia Social: sumário das lições magistrais e dos assuntos dos exercícios práticos, [Faculdade de Direito de Lisboa, Lisboa], 1919. Anos letivos de 1913-1914, 1914-1915, 1916-1917: regência de Fernando Emydio da Silva; ano letivo de 1917-1918: regência de Albino Vieira da Rocha; ano letivo de 1918-1919: regência de Martinho Nobre de Melo.

37 Para maior detalhe do pensamento de Fernando Emídio da Silva consulte-se: António Almodôvar, "Fernando Emídio da Silva (1886-1972)", en José Luís Cardoso (edit.), Dicionário Histórico de Economistas Portugueses, Temas e Debates, Lisboa, 2001, pp. 303-305.

38 Foi consultada a versão traduzida para italiano em: Gianni Arrigo y Gaetano Vardaro (edit.), Laboratorio Weimar: conflitti e diritto del lavoro nella Germania Prenazista, Edizioni Lavoro, Roma, 1982, p. 224. 
situação dos trabalhadores continuou sem ser reconhecida como competência daqueles, sendo feita no sentido imposto pelo Estado. Nesta lógica, teve lugar o debate pelo dia das oito horas de trabalho, que continuou a ser de dez, até ao decreto de 10 de maio de 1919.

Este aspeto aponta para outra característica importante, transversal à regulação do trabalho no século XIX e primeiras décadas do século XX em Portugal, o facto dos trabalhadores não terem tido participação direta nos instrumentos normativos que os tutelavam, isto é, estes foram concebidos, quase sem excepção, pelo poder executivo e muito poucos passaram pela organização parlamentar, nos periodos do seu funcionamento. Contabilizando apenas os principais diplomas publicados entre 1880 e $1926^{39}$, chegam-se aos seguintes resultados por matérias específicas: i) Tribunais dos árbitros avindores: uma carta de lei, catorze decretos e três portarias; ii) Trabalho de menores e de mulheres: seis decretos, uma lei; iii) Segurança e higiene no trabalho: dezoito decretos, uma portaria; iv) Associações de Socorros Mútuos: doze decretos, onze portarias; v) Situação do operariado industrial: seis decretos, duas portarias; vi) Bolsas de trabalho: dois decretos, uma lei; vii) Associações de Classe: sete decretos, três portarias, três leis; viii) Descanso semanal, horário de trabalho e duração do trabalho: cinco decretos, sete portarias, duas leis; ix) Greve: dois decretos, uma lei; x) Acidentes de trabalho: dois decretos, duas portarias e uma lei; xi) Aposentação: dois decretos, uma lei; xii) Previdência Social: dois decretos.

Alguma mudança de perspetiva sofrerá, porém, o ensino de Economia Social, no final de 1920, período já coincidente com uma situação política de ditadura militar, instaurada pelo golpe militar de 28 de Maio de 1926. No diálogo que a disciplina procurava estabelecer com a realidade internacional, surgia como questão principal a construção de um modelo alternativo à revolução comunista e às suas propostas de solução para a "questão social". No curso de 1928-1929, as lições de João Pinto da Costa Leite (Lumbrales), já atrás citadas, determinavam a "insuficiência do coletivismo marxista" naquele desígnio: o Estado centralizador e detentor de todos os instrumentos de produção, o desaparecimento da moeda, a associação do valor de um produto ao número de horas de custo da sua produção, o fim da liberdade de consumo, etc. A experiência da revolução russa de 1917 e de construção do direito soviético, com destaque para a Declaração dos Direitos do Povo Trabalhador e Explorado, eram amplamente comentados a este propósito, a partir de uma posição fortemente anticomunista. A associação profissional, promovida pelas escolas socialistas, mas também pelo sindicalismo como doutrina, era especialmente denegrida, não pelo empenhamento na melhoria das condições de vida do trabalhador, mas pela finalidade última que lhe era atribuida de fazer desaparecer o patronato e o salário. Embora fosse reconhecida uma assinalável diversidade no campo do sindicalismo doutrinário (revolucionário, reformista, católico), o repúdio pelas

39 Utiliza-se aqui o seguinte levantamento de legislação: Pedro Furtado Martins, Luís Bigotte Chorão e Maria João Adegas, Contributo para a História do Direito de Trabalho em Portugal. Recolha de referências legislativas até 1926, Ministério do Trabalho e da Segurança Social, [198-], [Lisboa], p. 1 e ss. 
suas propostas recaía na existência do sindicato como meio de luta, independentemente do processo. A greve geral defendida pelo sindicalismo revolucionário, de inspiração soreliana, era a experiência considerada mais violenta. O guild-socialism era também reprovado, identificado com a exaltação do produtor. Maior complacência era demonstrada quanto ao "sindicalismo técnico" que era associado a Walter Rathenau, e às propostas do chamado "sindicalismo católico", cujas fontes eram consideradas as encíclicas papais, a escola social de Le Play, atualizada mais tarde por Tourville e Demolins. Sobre o primeiro, era bem recebida a proposta da arbitragem dos conflitos entre patronato e operários. Quanto ao segundo, julgado demasiado ecléctico, era valorizada a ideia de os sindicatos desenvolverem atividade social, mas tida como menos feliz a impossibilidade de se recomendar uma solução unitária. Ainda assim, de todas as experiências, o sindicalismo católico era tido como "aquele que mais garantias de paz nos oferece" 40 .

O ambiente que o País atravessava, desde o final da I Guerra Mundial, contribuía para o exacerbamento de um combate ideológico contra o marxismo e contra as propostas mais radicais das correntes socialistas. O longo ciclo de recessão que dominara toda a República, assinalado por maus anos agrícolas, problemas de subsistências, de abastecimentos e de subida de preços, agravarase com novos cortes orçamentais e desvalorização da moeda, provocando novo surto de greves e paralizações do trabalho. No movimento sindical, a tendência revolucionária-anarquista ganhara força sobre a tendência socialista-reformista e dava passos inéditos na internacionalização das suas estruturas. Em 1919, formara-se a Confederação Geral dos Trabalhadores (CGT), de orientação anarquista, que representava todas as forças operárias, vindo a aderir à Associação Internacional dos Trabalhadores em Berlim (1922). Divergências de orientação levariam à saída dos sindicatos comunistas da CGT, em 1924, e à sua integração na Internacional Sindical Vermelha. O terrorismo, através de atentados e bombas, utilizado por grupos radicalizados como a Legião Vermelha, gerava novas ameaças, que determinavam um aumento da repressão estatal e também o encerramento de estruturas associativas (a CGT acabaria dissolvida em 1927).

A relação dos Governos com o associativismo patronal deteriorava-se também, motivada por tensões que envolviam o crescente intervencionismo dos Executivos e da administração central nos processos económicos, controlando transações, agravando burocracias e afastando representantes associativos de conselhos superiores consultivos (alguns substituidos por serviços internos de Ministérios) ou dos serviços técnicos de tribunais superiores. Afectado na sua liberdade de atuação, sofrendo nalguns casos ilegalizações, o associativismo patronal desenvolveria um posicionamento agressivo face ao sistema politico, criando programas económico-políticos próprios, competindo com os partidos, a nivel eleitoral e extra-eleitoral, e convergindo no nacionalismo económico e na resolução do problema da falência de autoridade do Estado no controle da ordem

40 Belmiro Pereira, Economia social. Segundo o plano das prelecções do Exmo. Sr. Doutor João Pinto da Costa Leite (Lumbrales) ao curso do 3. ${ }^{\circ}$ ano jurídico (1928-1929), op. cit., pp. 32-44. 
pública. Por razões diferentes, o movimento associativo, quer de trabalhadores, quer patronal, contestou ainda fortemente a legislação sobre trabalho (a lei das 8 horas e 48 semanas), seguros (que se tornaram obrigatórios) e acidentes de trabalho, publicada em 1919 e 1920 e de incipiente aplicação, face ao seu caráter estatizante, associado à obrigatoriedade dos descontos de previdência e à fiscalização das entidades associativas, estrangulador da liberdade de associação. A situação do Ministério do Trabalho e Previdência Social (criado em 1916) tornou-se também insustentável, ao ponto de ser extinto e os seus serviços dispersos por várias tutelas $(1925)^{41}$.

Neste cenário, a disciplina de Economia Social não serviria como lugar de acolhimento de um dos principais principios que iluminavam o novo "direito do trabalho", desenvolvido por Sinzheimer na Alemanha pré-weimariana e rececionados na futura Constituição de 1919, a ideia de "Kollektivismus" (não por acaso, Sinzheimer foi um autor silenciado entre os juristas e publicistas portugueses, nesta época), e punha também em causa a orientação das relações entre Estado, trabalhadores e empresários, que a legislação do trabalho publicada entre 1919-1926 tinha procurado gerar. A hostilidade votada à configuração conflitual das relações sociais despertava, em alternativa, a recuperação de orientações favoráveis a propostas institucionais com prevalência de uma função mediadora, destinadas a harmonizar tensões sociais. Donde se assumisse, por exemplo, quanto às doutrinas que justificavam o contrato coletivo de trabalho, uma preferência pela teoria de Hauriou, a "teoria da instituição corporativa". Elogiava-se a tendência, manifesta em alguns países, como a França, de desenvolvimento de um regime económico corporativo, onde o contrato coletivo de trabalho sugeria uma ordem jurídica nova, e onde as redes sindicais, na sua atividade reguladora e fiscalizadora, determinavam "novos serviços públicos, por meio dos quais, o Estado, o público, o comércio e a indústria se vão integrando coativamente a dentro do novo direito que nasce". Não se fazia a defesa objetiva de contratos coletivos impostos pelo poder público, mas essa possibilidade era já apresentada. Apesar de tais posições, os juristas não avançavam com uma solução especifica para Portugal, onde a discussão continuava em torno de se saber se o contrato coletivo era já uma figura existente ou não, prevalecendo a resposta positiva que já havia sido dada por Marnoco e Sousa, que entendia que as associações profissionais tinham capacidade para estabelecer aquele tipo de contratos, em virtude do estabelecido nos arts. ${ }^{\circ} 1 .^{\circ} \mathrm{e}$ 4. ${ }^{\circ}$, n. ${ }^{\circ} 1$ do decreto de 9 de maio de 1891. Para outros aspetos da regulamentação do trabalho, como o estabelecimento da duração do dia de trabalho, do descanso semanal (assumindo-se a defesa do domingo), da higiene e segurança dos trabalhadores, a ideia da legítima intervenção do poder político mostrava-se consolidada, admitindo-se inclusivamente a sua expansão, por

41 Dorothea Hoehtker y Sandrine Kott, À la rencontre de l'Europe au travail. Récits de voyages d'Albert Thomas (1920-1932), Publications de la Sorbonne/ Bureau international du Travail, Paris, 2015, pp. 273-275; Luís Aguiar Santos, Comércio e Politica na Crise do Liberalismo, Colibri, Lisboa, 2004, pp. 164 segg.; Nuno Luís Madureira, A Economia dos Interesses. Portugal entre as Guerras, Livros Horizonte, Lisboa, 2002, pp. 22-40; Álvaro Garrido, Cooperação e Solidariedade: Para uma História da Economia Social, Tinta da China, Lisboa, 2016, pp. 180-189. 
exemplo, quanto às férias anuais ou aos seguros sociais (estabelecidos para a invalidez, velhice e doença pelo decreto n. ${ }^{\circ}$ 5638, e para os desastres de trabalho, pelo decreto n. ${ }^{\circ}$ 5637, ambos de 10 de Maio de 1919). No caso dos seguros sociais, permanecia uma indefinição. Em 1929, haviam sido publicados os decretos n. ${ }^{\circ} 15342$ e 15313 que promulgavam a organização dos seguros sociais obrigatórios; todavia, haviam sido suspensos, com o argumento de representarem um encargo não suportável para o Estado, e ficariam por executar, bem como o decreto n. ${ }^{\circ}$ 15312, que criava a Caixa Nacional de Previdência ${ }^{42}$.

Da ideia de proteção do trabalho, como formulada pela ordem republicana o Estado e o dador de trabalho, nas suas esferas próprias, reconheciam ao trabalhador uma certa assistência de natureza patriarcal - subsistiam aproveitamentos, todavia, de forma titubeante (possivelmente relacionada com a própria debilidade das finanças públicas), começava a ser enfocada a ideia de uma assistência social. Uma nova atenção ao trabalhador emergira, gradualmente, do facto de não ser tomado como cidadão, mas como homem vinculado a qualquer interesse social. Para uma nova disposição sobre a assistência, concorria ainda o diagnóstico de que as instituições promovidas quer pelo associativismo operário (sindicatos, cooperativas e instituições de previdência orientadas pelo princípio mutualista), quer pelo empresariado (bairros operários, escolas para filhos de operários, lactários e creches) eram em número insuficiente para melhorar as condições de vida dos trabalhadores. A pobreza de recursos do País adensava essa realidade e, também por aqui, se insinuava a necessidade de intervenção do Estado e da sua "natural função coordenadora das atividades sujeitas à sua soberania"43.

\section{O PROCESSO DE CONSTITUCIONALIZAÇÃO E A AMBIÇÃO DE REFORMA DO ESTADO}

O processo de constitucionalização, iniciado durante a Ditadura Militar, a partir de 1930, incorporou as tendências, chamadas na época de "neocorporativas", que se discutiam nas Faculdades de Direito. Ainda que permaneça pouco estudado esse período, continuando por esclarecer o sentido de algumas iniciativas políticas (e até da sua negociação) e da própria legislação, que parecem constituir a génese de muitas soluções adoptadas pelos primeiros Governos de Salazar (inclusivamente quanto ao Estatuto do Trabalho Nacional e à legislação corporativa, publicada de 1933 em diante), pode-se afirmar que para o legislador constituinte o principal desafio residia na reorganização do Estado. Era dominante a ideia de crise das instituições democráticas provocadas pelo mau funcionamento do poder legislativo e pela fraqueza e mudança permanente do poder executivo ${ }^{44}$. Argumentava-se que eram poderes incapazes de orientar,

42 Exposição do conselho de administração acerca dos serviços do Instituto de Seguros Sociais Obrigatórios e reduções no orçamento, Boletim de Previdência Social, n. ${ }^{\circ}$ 19, 1929, pp. 8-9.

43 Belmiro Pereira, ,Economia social. Segundo o plano das prelecções do Exmo. Sr. Doutor João Pinto da Costa Leite (Lumbrales) ao curso do 3. ${ }^{\circ}$ ano juridico (1928-1929), op. cit., p. 234.

44 Entre 1910 e 1926, realizaram-se em Portugal oito eleições legislativas, de dois em dois anos e as legislaturas demoraram em média 1,8 anos. Formaram-se 45 executivos, 45\% dos quais em 
dirigir e fiscalizar a atividade nacional - o "Estado liberal não queria intervir". Ao terem, alegadamente, separado a política da economia, esses poderes haviam afastado as forças sociais da Constituição e do funcionamento do Estado, o que resultara na desumanização da economia e na luta das classes - o "Estado patrocinava o capitalismo, a exploração de uns homens contra os outros" e contra o próprio aparelho estatal ${ }^{45}$. Alguns verberavam ainda contra o "absurdo que o Governo provisório da República cometeu, concedendo aos operários o direito à greve"46. No fundo, movia-os o imperativo de completa dissociação da experiência republicana, com exceção para o curto período sidonista, onde haviam sido procuradas soluções proto-corporativas na gestão dos diferentes interesses pelo Estado.

Paralelamente, impunha-se a necessidade de superar a "questão social". Uma primeira tentativa da Ditadura Militar passara pela publicação da legislação corporativa de 1931 (decreto-lei n. 20342 de 24 de setembro), que desenvolvia uma "democracia orgânica" para o País, com criação de uma teia complexa de organismos corporativos desde o nivel concelhio até ao nacional (onde se seguia o princípio da representação conjunta de trabalhadores e empresários), que culminava na instauração de um Conselho Superior de Economia Nacional. Recebido com forte hostilidade, quer pelos sindicatos livres, quer pelo empresariado, o diploma não chegou a ser posto em prática ${ }^{47}$.

A preparação de um novo projeto constitucional, neste contexto, não é, portanto, separável de um acumular de experiências ineficazes e de um propósito de reforma do Estado, que haveria de assentar em três aspetos: redefinição do sistema político e reorganização dos interesses organizados e reelaboração da identidade tradicional do direito público do País. Para as diferentes forças politicas, apoiantes da ditadura, o elemento agregador e legitimador da mudança de orientação do que tinha sido, até aí, a relação dos poderes públicos com a sociedade, foi uma concepção organicista de Estado. Genericamente, servia, num primeiro plano, como uma ferramenta politica: definia que o Estado representava e defendia uma tal multiplicidade de interesses, que estava impedido de se subordinar a "um pensamento de classe ou dedicar-se à exclusiva satisfação das reivindicações desta" 48 . Deste modo, contrariando a imagem construída pelos adeptos do individualismo, da Nação como um mecanismo formado por

coligação e com uma duração média de 93 dias. Cf. Fernando Catroga, "Transição e Ditadura em Portugal nos primórdios do Século XX”, en Rui Cunha Martins (edit.), Portugal 1974. Transição Politica em Perspetiva Comparada, Imprensa da Universidade de Coimbra, Coimbra, 2011, pp. 4445.

45 Marcelo Caetano, Lições de Direito Corporativo, Livraria Moraes, Lisboa, 1935, pp. 13-14.

46 Luís Cunha Gonçalves, Principios de Direito Corporativo, Oficinas Gráficas, Lisboa, 1935, pp. 62-71.

47 José Barreto, “Estatuto do Trabalho Nacional”, en António Barreto y Maria Filomena Mónica (edit.), Dicionário de História de Portugal, vol. VII, Livraria Figueirinhas, Porto, 1999, pp. 681-682.

48 António Oliveira Salazar, "A organização integral da Nação e os interesses do trabalho", en O Trabalho e as Corporações no Pensamento de Salazar, Biblioteca Social e Corporativa, Lisboa, 1960 , p. 24. 
indivíduos soberanos, apresentava-se agora aquela como um organismo, constituído por individuos diferenciados, com atividades diferentes, hierarquizados na sua diferenciação natural. Esse organismo alimentava uma unidade de tempo (a solidariedade dialética entre presente, passado e futuro), onde se exprimiam funções específicas que colaboravam para um bem comum, realizado num espaço unitário (o território) ${ }^{49}$. Num segundo plano, constituía uma ferramenta económica: não só o Estado conhecia a vida económica, protegendo-a e dirigindo-a, em harmonia com os interesses políticos do momento, como os "elementos económicos - as forças produtivas - entram na orgânica do Estado", fazendo parte da sua constituição. Mais difusamente, surgia como ferramenta ideológica: inspirando ao Estado uma outra atuação, fortalecia o perseguir de um "progresso económico indispensável" e indissociável da "restauração e desenvolvimento de valores espirituais", designadamente pela libertação da "filosofia materialista, condenada pelos próprios males que desencadeou"50.

O carácter genérico de tal concepção, para a qual cada força política envolvida (da Esquerda Democrática ao Partido Republicano Nacionalista) encontrava diferentes fundamentações, conduziu a que se chegasse a uma referência corporativa na Constituição de 1933. Nessa escolha, como já tive oportunidade de analisar noutros locais ${ }^{51}$, jogava-se a aposta numa ideia tida, no tempo, como moderna e modernizadora, aflorada e construída na evolução europeia do Direito público. Esse propósito de cruzamento da realidade nacional com o cenário europeu da época, que se encontra no escrito de Salazar, citado no início deste artigo, encontrava ainda dilatação na conceção de "racionalização do poder", que vinha empregnando os estatutos constitucionais surgidos depois de 1919. Toda a ação do Estado devia basear-se no direito e ser penetrada por ele, jurisdicizando o que se entendia ser a "vontade do povo", a qual, interpretada pelos novos legisladores constituintes, determinava o reforço do poder executivo, a limitação do poder das assembleias legislativas, o estabelecimento de diversos sistemas de representação de interesses, o repúdio do conceito liberal clássico de "Soberania popular" 52. Todos os membros do povo formavam, agora, uma totalidade que se identificava como vontade superior, a vontade nacional, a qual, por sua vez, era determinada por considerações superiores de interesse geral.

49 Decálogo do Estado Novo, Secretariado de Propaganda Nacional, Lisboa, 1934, pp. 19-20.

50 António Oliveira Salazar, “A organização integral da Nação e os interesses do trabalho”, op. cit.

51 Paula Borges Santos, "Na génese da Constituição Política de 1933: o ideário corporativo e a estrutura econômico-social do autoritarismo português”, Estudos Históricos Rio de Janeiro, n. ${ }^{\circ}$ 64, 2018, pp. 173-196; Paula Borges Santos, "O modelo político do Estado autoritário português: a ideia corporativa na constitucionalização do regime (1931-1933)”, Espacio, Tiempo y Forma, n. ${ }^{\circ} 27,2015$, pp. 59-84.

52 R. C. van Caenegem, Uma Introdução Histórica ao Direito Constitucional Ocidental, Fundação Calouste Gulbenkian, Lisboa, 2009, pp. 293-297. 


\subsection{A adaptação do constitucionalismo de Weimar na Constituição de 1933}

Neste quadro, não surpreendem as notas manuscritas de Salazar, onde previa a introdução de matérias sociais e económicas no futuro texto constitucional português, inspirado na formulação da Constituição alemã de 1919. Aí se percebe também, o que não é menos importante, que não tinha intuito de mimetizar soluções definidoras do ordenamento essencial da atividade social e económica. Convicto da importância de recriar soluções de feição "nacional", Salazar defenderá outras fórmulas para alcançar, igualmente, um resultado programático. Nesse aspeto havia uma intencionalidade: a de criar uma nova dinâmica, inspiradora de uma realidade projetada para futuro e ainda não realizada, através de princípios e normas, sobre a ordenação social, os fundamentos das relações entre individuos e grupos, mas também quanto à organização e disciplina da atividade económica. Como bem captou Pereira dos Santos, na época, a Constituição de 1933 detinha um carácter mais "animador" do que "estabilizador" da realidade 53 .

$\mathrm{Na}$ Constituição alemã de 1919, na definição das instituições políticas, o legislador reforçara as atribuições de vários órgãos do Estado. Por um lado, desenvolvera a legitimidade qualificada de "revolucionária" de um presidente do Reich, eleito diretamente pelo povo, que, numa posição proeminente face aos ministros, imprimia uma unidade de direção ao poder executivo e valorizava a autonomia do Governo face ao parlamento; por outro lado, expandira a legitimidade constitucional-parlamentar ${ }^{54}$. Em Portugal, a solução para o modelo de organização dos poderes do Estado refletiu a experiência weimeriana, no tocante ao reforço dos órgãos que formavam o poder executivo, com dois objetivos. Primeiro, a conciliação abstrata de aspirações transportadas por individualistas (identificados, sobretudo, com a defesa do sistema parlamentar), correntes socialistas (como elementos da Esquerda Democrática e do Grupo Seara Nova que vinham defendendo, apoiados no pensamento organicista de De Greff e de Oliveira Martins, uma nova configuração para o poder legislativo, onde competências técnicas coexistissem com as políticas, e o enaltecimento do tecnicismo do poder executivo) e antiliberais (representados no Integralismo Lusitano, onde prevalecia o interesse em fundar uma "democracia orgânica", com eliminação da representação de classes e instituição de sufrágios orgânicos nas eleições para os órgãos do Estado, câmaras de representação orgânica e conselhos corporativos ou um Conselho Económico que regessem a economia). Segundo, a estabilização da situação política, no sentido de excluir o regresso à experiência democratizante da I República, fundando uma nova etapa da democracia, distinta do sistema parlamentar e dos partidos, onde o poder se

53 Francisco. I. Pereira dos Santos, Un État Corporatif. La Constitution Sociale et Politique Portugaise, 2. ${ }^{a}$ ed., Librairie du Recueil Sirey/ Editora Educação Nacional, Paris/Lisboa, 1940, p. 33.

54 Constantino Mortati, "Una valoración de conjunto sobre la experiencia de la Constitución de Weimar" en La Constitución de Weimar, Editorial Tecnos, Madrid, 2010, pp. 31-32; Pierre Rosanvallon, Le Bon Gouvernement, Éditions du Seuil, Paris, 2015, pp. 124-125. 
destinava a ser exercido por uma oligarquia (posições em que ressoavam as teses weberianas da democracia plebiscitária).

O antiparlamentarismo difuso da época facilitou o aumento do poder executivo na Constituição de 1933. Formalmente, tal foi alcançado pela eleição por sufrágio universal do presidente da República. A inovação passou por inscrever esta modalidade no texto constitucional, à semelhança do que fora feito em Weimar; embora radicasse na experiência sidonista e na prática seguida durante a própria Ditadura Militar, como Vital Moreira já sugeriu e atrás se salientou. Para o reforço da legitimidade presidencial concorria um elemento, com o qual se pretendia também diminuir a I República: o alargamento do direito de voto (que continuava, não obstante, limitado jurídica e administrativamente). Também a questão da responsabilidade do presidente, como era equacionada pela Constituição, que determinava que este não respondia perante a Assembleia Nacional (a câmara de representação política), reforçava a sua posição sobre os outros órgãos políticos. Todavia, outros mecanismos determinaram uma centralização do poder na figura do Presidente do Conselho de Ministros e não no Chefe de Estado.

Com efeito, o principal reforço do poder executivo deu-se em mais uma inovação inspirada nos preceitos Constituição alemã de 1919, como foi argumentado nos anos de 1930 e 194055, através da consagração da atribuição de poderes especiais ao presidente do Conselho. O art. ${ }^{\circ} 106 .^{\circ}$, que declarava que o Governo era constituído pelo presidente do Conselho e pelos Ministros, seguia de perto o art. $^{\circ}$ 52. ${ }^{\circ}$ da Constituição de Weimar. Acentuava-se, no entanto, contrariamente ao que se consagrara para o Estado alemão no art. $^{\circ} 56 .^{\circ}$, uma dependência dos ministros em relação ao chefe do Governo. Com os poderes que possuía, e que algumas das revisões constitucionais seguintes aumentaram por via do alargamento da competência legislativa do Governo, o presidente do Conselho tornava-se a figura de ligação entre o Governo e o presidente da República, mas também entre este e a Assembleia Nacional. Se o Presidente da República, apesar da faculdade que tinha de nomear e destituir o Governo (art. ${ }^{\circ}$ $81 .^{\circ}, \mathrm{n} .^{\circ}$ 1) ou de dissolver a Assembleia (art. ${ }^{\circ} 81 .^{\circ}, \mathrm{n} .^{\circ} 6$ ), acabava por ficar na dependência do chefe do Governo (os seus atos deveriam ser referendados pelo Presidente do Conselho e pelo ministro ou ministros competentes), também a Assembleia Nacional não funcionou como contrapeso no sistema político.

O poder legislativo daquela Assembleia limitava-se à aprovação das bases gerais dos regimes jurídicos e, apesar de ter competência para rever a Constituição, tal não era suficiente para ter a possibilidade de modelar a politica geral do Estado. Ao contrário do Estado de Weimar, a Constituição portuguesa inibiu a legitimidade parlamentar, traçando um caminho de centralização governativa, incompativel com os fins da democracia. E, apesar da vocação da ditadura ser constituinte, isto é, conceber o espaço politico-legal em permanente

55 Francisco I. Pereira dos Santos, Un État Corporatif. La Constitution Sociale et Politique Portugaise, op. cit., pp. 284-285; Afonso Rodrigues Queiró, "O Novo Direito Constitucional Português (Algumas ideias fundamentais)", Boletim da Faculdade de Direito, vol. XXII, 1947, pp. $59-62$. 
construção, a prática política que a governação seguiu nas revisões constitucionais também não favoreceu o desenvolvimento da legitimidade constitucional da Assembleia Nacional. $\mathrm{Na}$ realidade, as alterações à Constituição, resultantes dos oito momentos de revisão que o regime conheceu, não resultaram de quaisquer processos de diferenciação institucional ou de inclusão social. Foram, sobretudo, variações dentro do mesmo modelo políticoconstitucional. Para tanto, terá concorrido o facto de não terem tido fundamento experimental ${ }^{56}$. Pelo contrário, estiveram relacionadas com a gestão de crises politicas do regime pelo Governo, que não demonstrou preocupação com a durabilidade das soluções constitucionais, mas interesse na chegada a consensos imediatos.

Também a fundação de uma nova noção de sociedade surgiu, quer nas várias versões preparatórias do texto constitucional, quer na sua forma final, nos preceitos que desenvolviam os direitos e os deveres dos chamados "elementos estruturais da Nação", que, pela primeira vez, no constitucionalismo português eram destacados: a família e as corporações morais e económicas. A primeira, objeto dos arts. $^{\circ} 11 .^{\circ}$ e $12 .^{\circ}$, era considerada fonte de conservação e desenvolvimento da raça, com direito reconhecido a educar os filhos, e fonte da ordem politica, representada na freguesia e no municipio. Sob especial proteção da Constituição, isto é, do Estado (agindo por medidas legislativas e administrativas), era colocada a situação económica da família, fixando-se o compromisso de regulação dos impostos tendo em conta os encargos familiares, de constituição do casal de família, de instituição de "lares independentes e em condições de salubridade". Com carácter de diretiva para o futuro, estabelecia-se que seria promovida a adoção do salário familiar, a proteção à maternidade e a cooperação (do Estado com a família) na educação dos filhos (em estabelecimentos de ensino tanto públicos quanto privados). A coesão familiar era um valor a preservar, integrante da moralidade pública (católica), como indicavam as disposições que exigiam que a família assentasse no casamento, obrigatoriamente registrado (tal como se exigia ao nascimento dos filhos), e na diferença de direitos estabelecidos para filhos legítimos e ilegítimos. Encontramse aqui afinidades e diferenças em relação ao texto constitucional alemão de 1919 (art. $^{\circ}$ 119). Em ambos os casos, os preceitos constitucionais não constituíam direito aplicável, mas unicamente princípios normativos para o legislador. Os dois evidenciaram uma concepção monogâmica de família, legitimada pelo casamento (a possibilidade de divórcio era omitida), que Walter Jellinek interpretou para Weimar como pretendendo criar uma relação de oposição com a ordenação comunista da sociedade 57 . Revelando maior conservadorismo, a Constituição portuguesa não estabelecia a igualdade jurídica entre os dois sexos (o direito civil era dominado por uma visão patriarcal, que mantinha a mulher sob laços de

\footnotetext{
56 Francisco Sá Carneiro, As revisões da Constituição Politica de 1933, Brasília Editora, Porto, 1971 , p. 50.

57 Walter Jellinek, "El processo de elaboración de la Constitución de Weimar" en La Constitución de Weimar, op. cit., p. 283.
} 
grande dependência), e introduziria uma distinção penalizadora entre filhos legítimos e ilegitimos.

A familia, as freguesias, os municipios e agrupamentos de municípios eram considerados detentores de direitos politicos (arts. ${ }^{\circ} 17 .^{\circ}$ e $19 .^{\circ}$ ); e, futuramente, viriam a eleger, respetivamente, as juntas de freguesia, as câmaras municipais e os conselhos de província. Às corporações morais e económicas reconhecia-se também a possibilidade de participação nesses sufrágios orgânicos, designadamente para as autarquias locais e conselhos de provincia (art. ${ }^{\circ} 18 .^{\circ}$ ). Teriam, a par das câmaras municipais, representação na Câmara Corporativa. As corporações revelaram-se complexas para o legislador constituinte. Nas versões preliminares do texto constitucional de 1933, pensou-se que poderiam ser políticas ou de funcionários públicos, e tomar parte na eleição do presidente da República e dos membros das câmaras legislativas. Essa orientação, que correspondia a definir um padrão de elevada relação institucional entre interesses organizados e centros de decisão politica, foi, contudo, abandonada no decurso do processo constituinte. A sua autonomia foi também limitada, cabendo ao Estado promover e auxiliar na sua formação, mas também o seu reconhecimento e regulação por normas especiais $\left(\right.$ art. $^{\circ} 14 .^{\circ}$ ). Terminaram circunscritas a objetivos científicos, literários, artísticos, de educação física, de assistência, beneficência ou caridade (art.16. ${ }^{\circ}$ ). Se aqui, novamente, havia um afastamento em relação ao Estado de Weimar, recuperavam-se duas noções que haviam enformado aquele constitucionalismo: a superação do principio individualista e, em seu lugar, a afirmação do primado do social, por um lado, e a intervenção do Estado, em nome da possibilidade de potenciar a sua eficácia, em organismos que, mesmo não sendo órgãos políticos, contribuíam para realizar uma finalidade do interesse coletivo, por outro lado.

A principal inovação, saída do processo constituinte, foi, todavia, a extensão com que na Constituição se abordou uma matéria que até aí não entrara no constitucionalismo português, e cuja regulação era feita minuciosamente por legislação ordinária: a vida económica (arts. ${ }^{\circ} 29 .^{\circ}$ a $41 .^{\circ}$ ). A ideia principal que dominou todo o Título VIII foi o propósito de intervenção do Estado na economia para criar fundações que permitissem atingir um horizonte de justiça social, melhorando especialmente os mais desprotegidos e os mais vulneráveis à concorrência e à exploração económica. Nessa formulação não se rejeitava, à semelhança do que fora seguido na Constituição alemã de 1919, um acolhimento de posições socialistas em sentido amplo, designadamente no que envolvesse a contenção da atuação de "interesses parasitários", incompativeis com a distribuição equilibrada dos bens (e que, por exemplo, elementos do Grupo Seara Nova preconizavam, distanciando-se também de posições do socialismo revolucionário). A aparente harmonização que se buscava não anulava, contudo, o fundamento da propriedade, a estrutura da empresa individual e a sua responsabilidade (entendida não já como exclusivamente individual, mas também social). Foi reconhecido o direito à propriedade e à sua transmissão hereditária, nas condições determinadas pela lei civil (art. $\left.{ }^{\circ} 8 .^{\circ},{ }^{\circ}{ }^{\circ} 15\right)$. Fixava-se ainda que a propriedade, a par do capital e do trabalho, tinha uma função social, podendo como tal a lei determinar as condições do seu emprego e exploração (art. ${ }^{\circ} 35 .^{\circ}$ ). Consagrava-se a liberdade de indústria ou comércio, a par da liberdade de escolha de profissão ou género de trabalho (art. ${ }^{\circ} 8$, n. $^{\circ} 7$ ). No entanto, não eram 
liberdades plenas nem efetivas, porque estavam sujeitas às restrições impostas pelo bem comum e a exclusivos que o Estado e os corpos administrativos entendessem conceder.

Sobre o trabalho, no decurso do processo constituinte, o legislador eliminou a interpretação de que aquele era elemento da empresa económica e restringiu o papel e as atribuições das associações sindicais, ao ponto de, por fim, nem as mencionar na Constituição. O repúdio da luta de classes transpareceu na omissão da questão da liberdade sindical e na proibição da "suspensão da atividade" laboral (greve e lock-out) (art. ${ }^{\circ} 39 .^{\circ}$ ). Depreendendo-se que sobre a primeira pesavam as limitações do direito de associação. A capacidade de celebração dos contratos coletivos de trabalho, prevista inicialmente para os sindicatos, passou, neste espírito, para as corporações económicas, sendo nulos os que se celebrassem sem a sua intervenção (art. ${ }^{\circ} \quad 37 .^{\circ}$ ). Estabeleciam-se tribunais especiais para julgar os litígios relativos às relações coletivas de trabalho (art. ${ }^{\circ} 38 .^{\circ}$ ). Em benefício da comunidade e com um sentido moralizante, o Estado assumia para si o direito e a obrigação de defesa da salubridade, da alimentação e da higiene pública (art. ${ }^{\circ} 400^{\circ}$ ); declarava-se a sua proteção às instituições de solidariedade, previdência, cooperação e mutualidade $\left(\operatorname{art}^{\circ}{ }^{\circ} 41 .^{\circ}\right)$. Tendo sido a experiência constitucional de Weimar a legitimar um tratamento extensivo das matérias económicas e sociais na Constituição de 1933, as soluções consagradas em ambas foram totalmente distintas. Em Portugal, não se criaram quaisquer organismos económicos que pudessem intervir na função legislativa, como sucedia com as criações do Reichsrat e do Conselho Económico do Estado de Weimar. Tão pouco a Câmara Corporativa, onde tinham assento elementos de diversos interesses económicos, ou as corporações económicas, previstas no caso português, tinham esse poder. A Câmara Corporativa tinha somente um papel consultivo e, como tal, não vinculante para as decisões do poder executivo ou da Assembleia Nacional. A lógica dos contrapesos entre poderes, seguida parcialmente em Portugal para o plano da organização politica, não teria para a organização da vida económica qualquer aplicação.

\section{CONCLUSÃo: A CONSTITUIÇÃo DE 1933 E O MOVIMENTO CONSTITUCIONAL NO SÉCULO XX PORTUGUÊS}

Foi traçado, ao longo deste artigo, um percurso de ideias e argumentos do direito convocados para interpretar os problemas politicos, sociais e económicos que Portugal atravessou nas três primeiras décadas do século XX. Nessa época, o discurso jurídico manteve-se atualizado em relação às tendências contemporâneas, prevalecendo uma pluralidade de receções de escolas, de doutrinas e de autores. A dimensão comparada foi cultivada nas Faculdades de Direito de Coimbra e de Lisboa, atentas às experiências da Alemanha, da Rússia, da Grã-Bretanha, da França, da Bélgica e da Itália, e também, embora com menor incidência, aos Estados Unidos da América. As transformações no direito motivadas pela I Guerra Mundial foram também amplamente refletidas, sobretudo quanto aos novos domínios legislativos e ao constitucionalismo europeu pós-bélico. Serviram, especialmente, para enformar propostas para necessidades objetivas da realidade nacional, mas que não ganharam de imediato coerência e permaneceram compósitas, manifestando influências concomitantes. 
$\mathrm{Na}$ discussão das melhores soluções para a crise do parlamentarismo e da chamada "questão social", desde a década de 1920, prevaleceu a superação do princípio individualista e a afirmação da prioridade do social. Esta inclinação, que paulatinamente se foi consumando, fora introduzida por correntes organicistas, por um lado, e por correntes socialistas, por outro. A reestruturação do sistema político e da vida económica espelharam o fenómeno da socialização do direito. Porém, sem implicar, nos momentos fundacionais ou no processo de constitucionalização da ditadura, uma ativação das massas. A ameaça que a revolução bolchevique constituía (para um amplo leque da opinião política, desde a ala moderada do Partido Democrático até às forças que vieram a ser os principais apoios do futuro regime autoritário), bem como todas as manifestações de socialismo revolucionário, determinaram soluções empenhadas em pacificar a comunidade, por via da intervenção do Estado, como intérprete do interesse nacional. As ideias de um poder executivo dominante, de anulação do conflito de classes através da criação de construções artificiais, que deveriam reproduzir a organização da sociedade, ou a elevação da economia a interesse público (isto é, a interesse do Estado, permitindo a consagração de uma ampla margem de intervenção do poder estatal na gestão da economia), foram os pontos fortes da nova construção constitucional.

Sobre o constitucionalismo de Weimar foi feita uma apropriação negativa, que implicou a rejeição do seu horizonte democrático. Essa inspiração não foi negada pelo poder constituinte e foi compreendida por juristas e intelectuais da época com a naturalidade própria de quem estava familiarizado com os referenciais usados. Essa perspetiva perdeu-se ao longo do tempo, ao ponto de existir na atualidade dificuldade em relacionar ideias que circularam de um constitucionalismo democrático para outro não democrático. Para o fenómeno de opacidade que cobre, hoje em dia, essa difusão, pode ter concorrido o tremendo sucesso que teve a construção jurídica sobre as doutrinas que influenciaram o legislador da Constituição de 1933, feita de imediato e aperfeiçoada posteriormente pelos professores de direito e jurisconsultos que assessoravam Salazar ou que vieram, pouco depois, a sair das universidades para exercer diversas funções governativas.

As adopções feitas às ideias da experiência constitucional de Weimar em Portugal coincidem temporalmente com críticas feitas por Hugo Sinzheimer às formas organicistas e à ideia de Standeverfassung ("constituição corporativista"), que percebia as primeiras como uma negação da autonomia do valor humano e a segunda como uma forma artificial de interromper a dinâmica social fundada no conflito de classes ${ }^{58}$. Esses riscos manifestar-se-ão em Portugal na governação que foi conduzida, sob os principios da Constituição, que serviram como instrumentos de conservação da ordem existente e deram cobertura à compressão dos direitos fundamentais, da iniciativa privada e da função social do trabalho e ao cultivo de uma dimensão moralizante da economia e da sociedade. Apenas com o final da II Guerra Mundial e as transformações que provocou no

58 Hugo Sinzheimer, "La crisi del diritto del lavoro (1933)", en Gianni Arrigo y Gaetano Vardaro (edit.), Laboratorio Weimar: conflitti e diritto del lavoro nella Germania Prenazista, op. cit., pp. 80-81. 
direito público, na política, na economia, ocorreram alterações nos comportamentos políticos e nos discursos jurídicos, que voltaram a aprofundar, agora em sentido democrático, a socialização do direito, a que não foram alheias propostas para encetar um corporativismo democrático.

Este caminho conduziu a que a Constituição de 1976 não rompesse radicalmente com o texto constitucional que a precedeu, num aspecto: na consagração de princípios gerais, para a organização económica e social, que encerravam um carácter prospectivo. O fim transcendente apontado à sociedade portuguesa era agora o da sua transformação numa sociedade sem classes, assegurando a transição para o socialismo. Expandia-se agora a intervenção directa do Estado na economia, com convocação de novos recursos, por exemplo, a planificação do desenvolvimento económico (art. 50. ${ }^{\circ}$ ). O Estado surgia como fim da coordenação e regulação da economia (arts. $81 .^{\circ}$ a $83 .^{\circ}, 84 .^{\circ} .1,85 .^{\circ} .3,89 .^{\circ}$ $2 ., 91 .^{\circ}$ a $95 .^{\circ}, 109 .^{\circ}$ e $110^{\circ}$ ), mantendo como incumbência social prioritária algo que também estivera presente sob o signo do autoritarismo: a promoção do aumento do bem-estar social e económico do povo, em especial das classes mais desfavorecidas. Na organização politica, não se abdicaria da eleição do poder executivo por sufrágio directo, retomando o legado da Constituição de 1933 (prevalecente até 1959) quanto à eleição do presidente da República.

Por tudo o que fica dito, é possível defender que houve um movimento constitucional gerado no começo dos anos de 1930, sob o signo do autoritarismo, que determinará referenciais que não mais abandonarão o século XX em Portugal. Inscrito no momento constituinte do autoritarismo, a sua reelaboração ocorreu na transição para a democracia e quando esta já estava consolidada (revisões à Constituição de 1976). Este movimento constitucional diferiu do constitucionalismo português característico do século XIX e, nos aspetos mais originais da sua formulação, apresentou pontos de contacto com aquele que foi o movimento constitucional supranacional do século XX europeu, despolotado com a Constituição alemã de 1919.

Fecha de envío / Submission date: 19/04/2019

Fecha de aceptación / Acceptance date: 4/05/2019 